\title{
Prolonged Exposure of Human $\beta$ Cells to Elevated Glucose Levels Results in Sustained Cellular Activation Leading to a Loss of Glucose Regulation
}

\author{
Zhidong Ling and Daniel G. Pipeleers \\ Diabetes Research Center, Vrije Universiteit Brussel, B-1090 Brussels, Belgium
}

\begin{abstract}
Human $\beta$ cells can be maintained in serum-free culture at $6 \mathrm{mmol} /$ liter glucose, with $80 \%$ cell recovery and preserved glucose-inducible functions after 1 wk. Between 0 and 10 $\mathrm{mmol} / \mathrm{liter}$, glucose dose-dependently increases the number of $\beta$ cells in active protein synthesis $(15 \%$ at $0 \mathrm{mmol} / \mathrm{liter}$ glucose, $60 \%$ at $5 \mathrm{mmol} / \mathrm{liter}$, and $82 \%$ at $10 \mathrm{mmol} / \mathrm{liter}$ ), while lacking such an effect in islet non- $\beta$ cells ( $>75 \%$ activated irrespective of glucose concentrations). As in rat $\beta$ cells, this intercellular difference in glucose sensitivity determines the dose-response curves during acute glucose stimulation of human $\beta$ cells. During 2-h incubations, human $\beta$ cells synthesize $7 \mathrm{fmol}$ insulin $/ 10^{3}$ cells at $0 \mathrm{mmol} /$ liter glucose, 20 fmol at $5 \mathrm{mmol} / \mathrm{liter}$, and $31 \mathrm{fmol}$ at $10 \mathrm{mmol} / \mathrm{liter}$. Culture at higher (10 or $20 \mathrm{mmol} / \mathrm{liter})$ glucose does not affect $\beta$ cell recovery but decreases by $50-85 \%$ the net effect of glucose upon insulin synthesis and release. These reduced responses to glucose are not caused by diminished cellular activities but are the consequence of a shift of $\beta$ cells to a state of sustained activation. The presence of more activated cells at low glucose eliminates glucose-dependent cell recruitment as a mechanism for adjusting $\beta$ cell responses to acute variations in glucose concentration. It leads to elevated basal biosynthetic (3-fold) and secretory (10-fold) activities, and, hence, to a 4-fold reduction in the $\beta$ cell insulin content and the amount of insulin released at maximal glucose stimulation. Prolonged exposure of human $\beta$ cells to high glucose can thus lead to a loss of their glucose regulation as a consequence of sustained cellular activation, without signs of glucose-induced toxicity or desensitization. (J. Clin. Invest. 1996. 98:28052812.) Key words: glucose • islets • insulin • diabetes
\end{abstract}

\section{Introduction}

Glucose is the major physiologic regulator of pancreatic $\beta$ cell functions. Patients with non-insulin-dependent diabetes exhibit a $\beta$ cell mass which has lost this homeostatic control by

Part of this work was presented at the 29th Congress of the European Association for the Study of Diabetes, Istanbul, 1993.

Address correspondence to D. Pipeleers, Diabetes Research Center, Vrije Universiteit Brussel, Laarbeeklaan 103, B-1090 Brussels, Belgium. Phone: 32-2-477-45-41; FAX: 32-2-477-45-45; E-mail: dpip @mebo.vub.ac.be

Received for publication 26 August 1996 and accepted in revised form 16 October 1996.

J. Clin. Invest.

(C) The American Society for Clinical Investigation, Inc.

0021-9738/96/12/2805/08 \$2.00

Volume 98, Number 12, December 1996, 2805-2812 the nutrient. Their chronically elevated glucose levels are believed to further impair the insulin secretory responsiveness to glucose (1-6). This concept has been documented in animal models of hyperglycemia (7-11) as well as in cultured islet cell preparations (12-15). It is still unclear whether the deleterious effects of persistently high glucose concentrations are the consequence of a glucose-induced toxicity (1-5), desensitization $(5,6,12,13)$, hyperactivation $(16,17)$, or exhaustion $(1,2,18)$ of the $\beta$ cells. In a recent study on rat islet $\beta$ cells, we found that chronic exposure to elevated glucose levels induces a prolonged state of $\beta$ cell activation and glucose hypersensitivity rather than a glucotoxicity or glucose desensitization (19). This shift in the functional state of the $\beta$ cell preparation is responsible for a reduced insulin secretory response to glucose (19). It is now important to assess whether this mechanism also occurs in human $\beta$ cells, in particular in view of the species differences which have been observed recently between human and rat $\beta$ cells (20). In this study, we first investigated whether the glucose responsiveness of human $\beta$ cells also depends on the existence of intercellular differences in glucose sensitivity as observed previously in rat $\beta$ cells (21-24). Then, we examined whether prolonged exposure to elevated glucose levels affects this functional heterogeneity and, as a consequence, impairs the glucose responsiveness of the human $\beta$ cells.

\section{Methods}

Preparation of human islets and dispersed islet cells. Human pancreata were obtained from organ donors (17 donors, 20-50 yr of age) at European hospitals affiliated with $\beta$-Cell Transplant, a European Concerted Action on islet cell transplantation in diabetes. Islets were prepared in the Central Unit of this multicenter program (Medical Campus, Vrije Universiteit Brussel). After collagenase digestion and Ficoll gradient purification (25), the islet-enriched interface was harvested, washed, and suspended in Ham's F10 medium supplemented as described below. The preparations were precultured for 1 or $2 \mathrm{~d}$ to reduce contamination by cell debris and exocrine cells. To examine the glucose sensitivity of individual cells, the precultured islet preparations were dispersed into single cells and further purified by flow cytometry using cellular light scatter as discriminating parameter (26). Immediately after dissociation and purification, $>90 \%$ of the cells stained positive in vital staining with neutral red. The purified fractions consisted of $70-85 \%$ endocrine cells, $10-20 \%$ nongranulated cells, and $2-8 \%$ exocrine cells. To examine the influence of chronic exposure to high glucose, undissociated islet preparations were cultured at different concentrations of glucose.

Culture. Freshly isolated human islet preparations were precultured for 1 or $2 \mathrm{~d}$ in bacteriologic Petri dishes $(14 \mathrm{~cm}$ diameter; Nunc, Roskilde, Denmark) with $35 \mathrm{ml}$ Ham's F10 medium containing $0.5 \%$ (wt/vol) BSA (fraction V, RIA grade; Sigma Chemical Co., St. Louis, MO), $0.075 \mathrm{mg} / \mathrm{ml}$ penicillin, and $0.1 \mathrm{mg} / \mathrm{ml} \mathrm{streptomycin,} 6.1 \mathrm{mmol} /$ liter glucose, $2 \mathrm{mmol} /$ liter glutamine, $2 \mathrm{mmol} /$ liter leucine, $2 \mathrm{mmol} / \mathrm{li}$ ter nicotinamide, and $2 \%$ human serum. After this preculture period, the islet preparations were either dissociated into single cells or distributed over Petri dishes and further cultured for $7 \mathrm{~d}$ in serum-free 
Ham's F10 medium containing 1\% BSA, 2 mmol/liter glutamine, and different concentrations of glucose. The cells were kept at $37^{\circ} \mathrm{C}$ in a $\mathrm{CO}_{2}$ incubator $\left(95 \%\right.$ air $\left./ 5 \% \mathrm{CO}_{2}\right)$ with medium changes every $3 \mathrm{~d}$.

Samples were taken after isolation, after dissociation, and at the end of culture for measuring the cellular insulin and DNA content, and for electron microscopy and immunocytochemistry (26). The viability of dispersed single islet cells was examined by vital staining with neutral red (27).

Total protein and insulin biosynthesis. Protein synthesis by single islet cells was measured after a 45-min preincubation in Ham's F10 medium containing $0.5 \%$ BSA and $1 \mathrm{mmol} /$ liter glutamine. The cells were then distributed into 5-ml Falcon tubes and incubated for 30 min in $200 \mu \mathrm{l}$ Ham's F10 medium containing different concentrations of glucose, $1 \% \mathrm{BSA}, 50 \mu \mathrm{Ci} \mathrm{L}-\left[3,5-{ }^{3} \mathrm{H}\right]$ tyrosine (specific activity $50 \mathrm{Ci} /$ mmol; Amersham International, Buckinghamshire, United Kingdom). The total tyrosine concentration was $15 \mu \mathrm{mol}\left(5 \mu \mathrm{mol}\left[{ }^{3} \mathrm{H}\right]\right.$ tyrosine and $10 \mu \mathrm{M}$ unlabeled tyrosine) and the specific activity of the tracer was $16.7 \mathrm{Ci} / \mathrm{mmol}$. When protein synthesis was measured in cultured islet preparations, the fractions were washed twice in Earle's Hepes medium and three times in Ham's F10 medium without glucose. This wash procedure took 40-60 min. Preparations were then incubated for $2 \mathrm{~h}$ under the same condition as dispersed cells. The labeling incubation was stopped by adding $0.8 \mathrm{ml}$ cold Earle's Hepes containing $1 \mathrm{mmol} /$ liter unlabeled tyrosine. After extensive washing the preparations were either extracted in $1 \mathrm{ml}$ acetic acid $(2 \mathrm{~mol}$ containing $0.25 \% \mathrm{BSA}$ ) for measurement of total protein and proinsulin biosynthesis (23) or processed for autoradiography.

Autoradiography of dispersed single islet cells and cultured islets. The use of autoradiographs for analyzing the protein synthetic activity of individual cells has been described previously $(23,24)$. The ${ }^{3} \mathrm{H}-$ labeled single cell preparations were washed with PBS, fixed in $4 \%$ (vol/vol) paraformaldehyde for $15 \mathrm{~min}$ at room temperature, washed with distilled water containing $0.5 \% \mathrm{BSA}$, and dried on polylysinecoated glass slides. The cells were then postfixed for $15 \mathrm{~min}$ in $4 \%$ (vol/vol) paraformaldehyde, and stained for insulin using a mouse antiinsulin serum and rhodamine-labeled second antibodies. The cells were also stained for DNA using bisbenzimidine (Hoechst 33342). The slides were then exposed for $4 \mathrm{~h}$ to an autoradiographic emulsion (L-4; Ilford Ltd., Basildon, Essex, United Kingdom), which was developed for $7 \mathrm{~min}$ in ID-11 (Ilford) at $20^{\circ} \mathrm{C}$ and then fixed for another $7 \mathrm{~min}$ in Hypam (Ilford). At least 200 insulin-positive or -negative cells were analyzed per condition. Autoradiographic silver grains were counted by epipolarization microscopy at a final magnification of 400. Background labeling, determined in parallel experiments without tracer, was $<2$ grains/cell. The cells with $>5$ silver grains were scored as positive and cells with $>30$ silver grains were classified as strongly positive.

The ${ }^{3} \mathrm{H}$-labeled islets were fixed with $2.5 \%$ glutaraldehyde, postfixed in $1 \%$ OsO4, and embedded in Spurr's resin before $1-\mu \mathrm{m}$ sections were prepared. Sections were etched with sodium methoxide and stained for insulin using a guinea pig antiinsulin serum and a peroxidase-labeled anti-guinea pig serum. The autoradiographs were exposed for $1 \mathrm{~d}$ and examined for silver grains on insulin-positive and -negative cells.

Measurement of insulin release. Cultured islet preparations were loaded on preformed columns consisting of $1 \mathrm{ml}$ swollen Biogel P2 (Biorad, Richmond, VA) and perifused with Ham's F10 medium supplemented with $0.5 \%$ BSA, $2 \mathrm{mmol} /$ liter glutamine, $2 \mathrm{mmol} / \mathrm{liter}$ $\mathrm{CaCl}_{2}$, and equilibrated with $95 \% \mathrm{O}_{2} / 5 \% \mathrm{CO}_{2}$ (28). After $20 \mathrm{~min}$ of perifusion with Ham's F10 containing $2.5 \mathrm{mmol} /$ liter glucose, 10-min pulses of glucose stimulation were induced with 5,10 , or $20 \mathrm{mmol} / \mathrm{li}$ ter glucose, and supplemented, at $20 \mathrm{mmol} / \mathrm{liter}$, with IBMX. At a flow rate of $1 \mathrm{ml} / \mathrm{min}$, samples were collected over $1 \mathrm{~min}$. At the end of each perifusion, the gels were removed from the column by suspension in $2 \mathrm{M}$ acetic acid/ $0.25 \%$ BSA. The acid cell extracts and the collected fractions were assayed for insulin (26).

Data expression. DNA content of cultured preparations was expressed as a function of the values at start, i.e., on the day of isolation.
Since cell counts could not be performed in the cell clumps, cell number was calculated on the basis of DNA content, assuming that $6.6 \mathrm{ng}$ DNA corresponds to $10^{3}$ cells. This value has been determined in single islet cell preparations. Cellular insulin content and insulin biosynthesis were expressed per $10^{3} \beta$ cells. Insulin release was expressed per $10^{3} \beta$ cells or as a function of the corresponding cellular hormone content. Results are expressed as means \pm SEM. Statistical significance of differences was calculated by ANOVA or by Student's $t$ test.

\section{Results}

Recovery of $\beta$ cells after culture at different glucose concentrations. After $7 \mathrm{~d}$ of culture in serum-free medium containing 6 $\mathrm{mmol} /$ liter glucose, the DNA content of the islet preparations was reduced to $53 \%$ of the values measured in freshly isolated preparations (Table I). The percentage of $\beta$ cells increased from $33 \%$ on day 1 to $53 \%$ on day 7 (Table I), indicating that the reduction in DNA content was mainly caused by loss of non- $\beta$ cells, with $80 \%$ of $\beta$ cells being recovered at the end of this culture period (Table I). The mean insulin content of the cultured $\beta$ cells was $75 \%$ of that in freshly isolated $\beta$ cells $(P>$ 0.05 , Table I). Culture at lower $(3 \mathrm{mmol} /$ liter $)$ or higher glucose (up to $20 \mathrm{mmol} / \mathrm{liter}$ ) did not significantly influence the recovery of $\beta$ cells, but resulted in a lower cellular insulin content (Table I). The highest degree of degranulation was noticed after culture at $20 \mathrm{mmol} /$ liter glucose, with a fivefold lower cellular insulin content than after $6 \mathrm{mmol} /$ liter glucose culture. Glucagon content was comparable in all cultured preparations (data not shown). In all conditions, the cultured preparations consisted of $>80 \%$ ultrastructurally intact cells as judged by electron micrographs (data not shown).

Glucose responsiveness of $\beta$ cells after culture at $6 \mathrm{mmol} / \mathrm{li}$ ter glucose. To determine the glucose responsiveness of individual cells, islets which had been cultured for 1 or $2 \mathrm{~d}$ at $6 \mathrm{mmol} /$ liter glucose were dissociated into single cells before incubating the cell suspension for $30 \mathrm{~min}$ with $\left[{ }^{3} \mathrm{H}\right]$ tyrosine at different glucose concentrations. Glucose dose-dependently increased the rates of total protein and proinsulin synthesis in these preparations. The rates of total protein and proinsulin synthesis increased, respectively, two- and sixfold when glucose was raised from 0 to $10 \mathrm{mmol} / \mathrm{liter}$ (Fig. 1); further increases in glucose did not lead to higher rates of proinsulin

Table I. Composition of Human Islet Preparations after Culture

\begin{tabular}{|c|c|c|c|c|}
\hline \multirow{2}{*}{$\begin{array}{c}\text { Cell } \\
\text { preparations }\end{array}$} & \multicolumn{2}{|c|}{ Recovery } & \multirow{2}{*}{$\begin{array}{c}\text { Percent } \\
\text { insulin-positive } \\
\text { cells }\end{array}$} & \multirow{2}{*}{$\begin{array}{l}\text { Insulin } \\
\text { content }\end{array}$} \\
\hline & DNA & $\beta$ cells & & \\
\hline & \multicolumn{2}{|c|}{$\%$ start } & & fmol/10 $\beta$ cells \\
\hline At start & 100 & 100 & $33 \pm 2$ & $5500 \pm 1016$ \\
\hline \multicolumn{5}{|l|}{$\begin{array}{l}\text { After } 7 \mathrm{~d} \text { of culture } \\
\text { at glucose }\end{array}$} \\
\hline $3 \mathrm{mmol} /$ liter & $56 \pm 12 *$ & $77 \pm 13$ & $48 \pm 4^{\ddagger}$ & $2215 \pm 430 *$ \\
\hline $6 \mathrm{mmol} /$ liter & $53 \pm 8^{*}$ & $82 \pm 8$ & $53 \pm 4^{\S}$ & $4072 \pm 718$ \\
\hline $10 \mathrm{mmol} /$ liter & $52 \pm 11 *$ & $71 \pm 11$ & $49 \pm 6^{\ddagger}$ & $3460 \pm 530^{\S}$ \\
\hline $20 \mathrm{mmol} /$ liter & $58 \pm 9 *$ & $88 \pm 8$ & $53 \pm 4^{\S}$ & $803 \pm 175^{* \|}$ \\
\hline
\end{tabular}

Data represent means \pm SEM of five to seven independent experiments. Statistical significance of differences was calculated by ANOVA, versus freshly isolated cells: ${ }^{\ddagger} P<0.05,{ }^{\circledR} P<0.01,{ }^{*} P<0.001$; vs. $6 \mathrm{mmol} /$ liter glucose: $\| P<0.05$. 

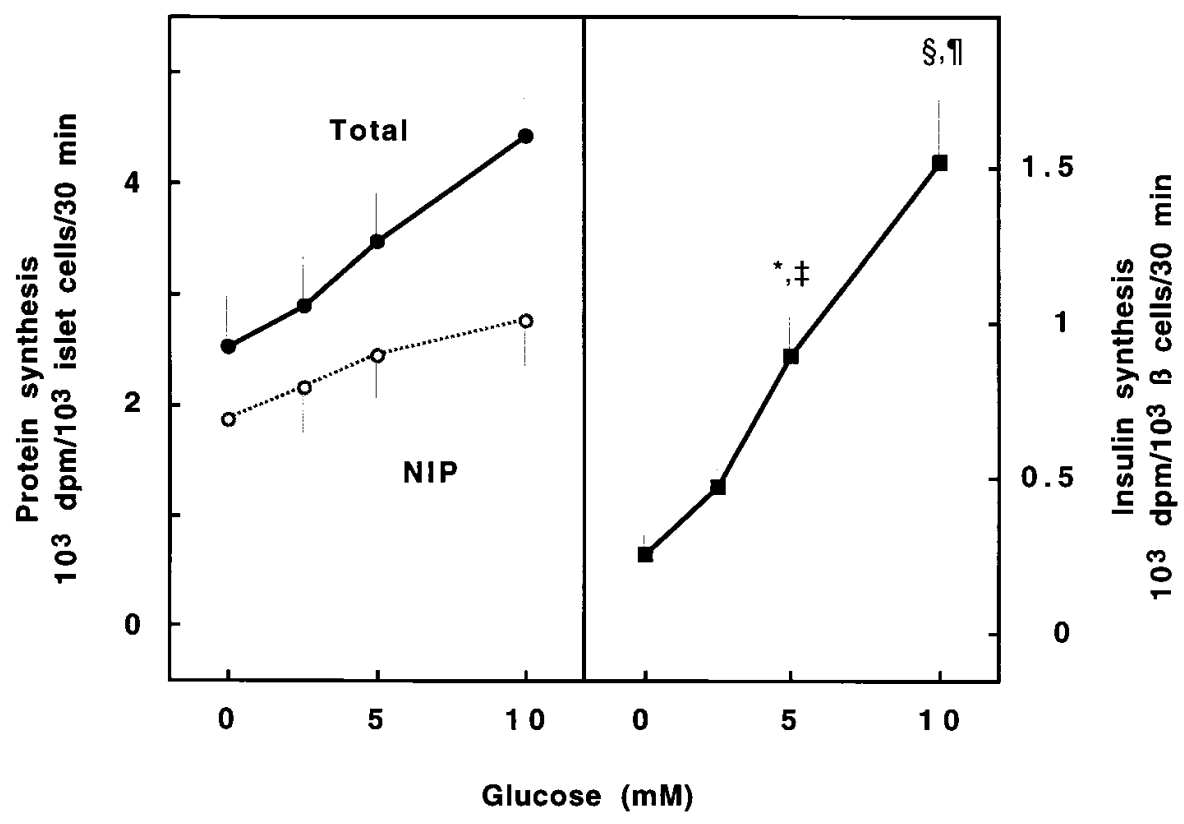

Figure 1. Effect of glucose on the synthesis of protein (left, Total), insulin (right), and noninsulin protein (left, NIP) by human islets. Data are expressed per $10^{3}$ cells for protein and NIP synthesis and per $10^{3}$ $\beta$ cells for insulin synthesis. Means \pm SEM are calculated from 7 to 10 independent experiments. Statistical significance of differences with $0 \mathrm{mmol} /$ liter glucose $(* \S)$ and with the preceding glucose level $(\ddagger \mathbb{I})$ are calculated by ANOVA. ${ }^{\ddagger} P<0.05$; *II $P<0.01 ;{ }^{\S} P<0.001$.
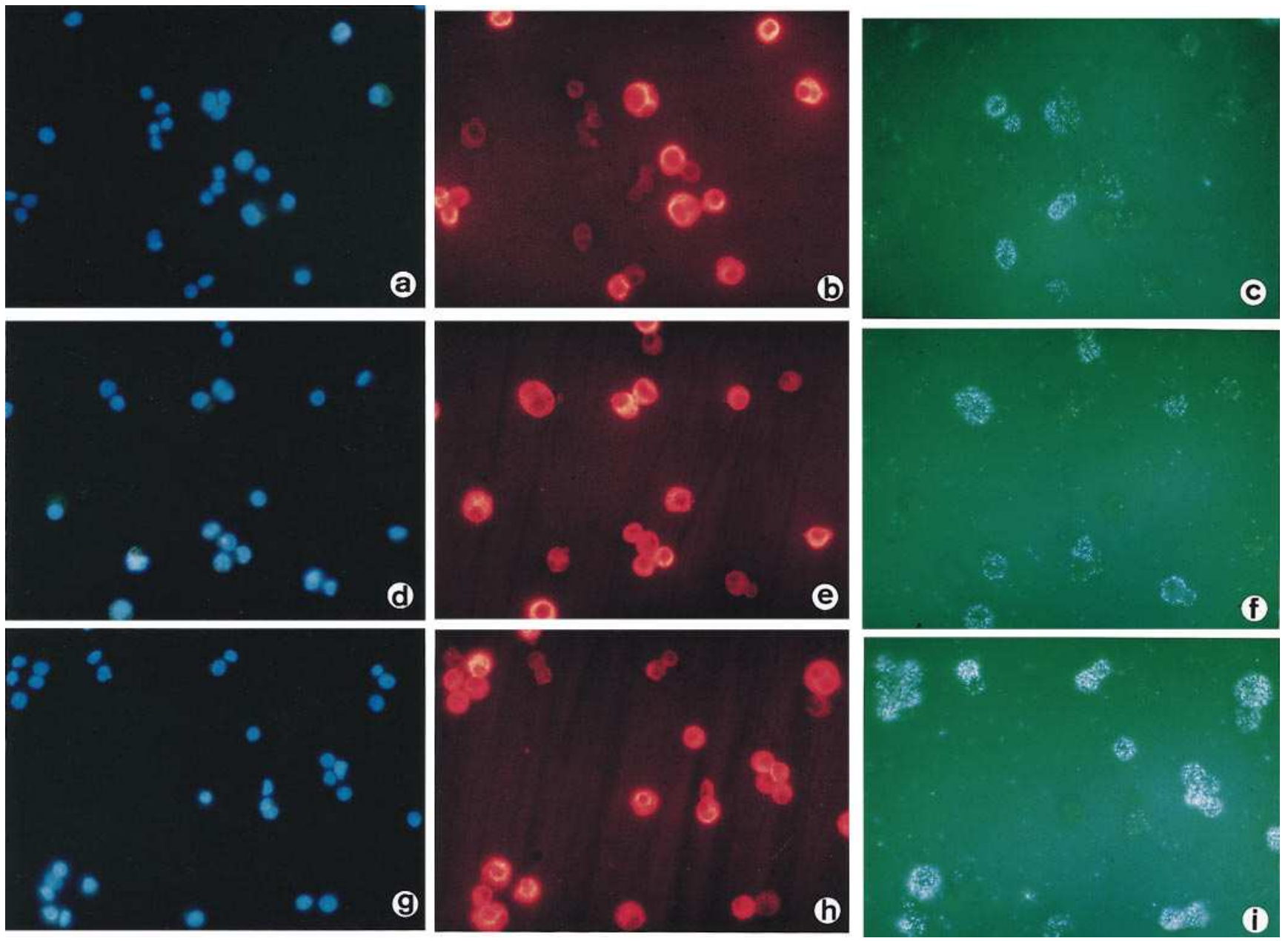

Figure 2. Effect of glucose upon $\left[{ }^{3} \mathrm{H}\right]$ tyrosine incorporation by human islet cells. The preparations were incubated with $\left[{ }^{3} \mathrm{H}\right]$ tyrosine for $30 \mathrm{~min}$ in the absence of glucose $(a-c)$, at $5 \mathrm{mmol} /$ liter glucose $(d-f)$, or at $10 \mathrm{mmol} /$ liter glucose $(g-i)$. Autoradiographs of the cells are shown in epipolarization microscopy $(c, f, i)$ after immunostaining for insulin $(b, e, h)$ and Hoechst staining for DNA $(a, d, g)$. Glucose dose-dependently increases the percentage of radioactively labeled insulin-positive cells. $\times 1060$. 


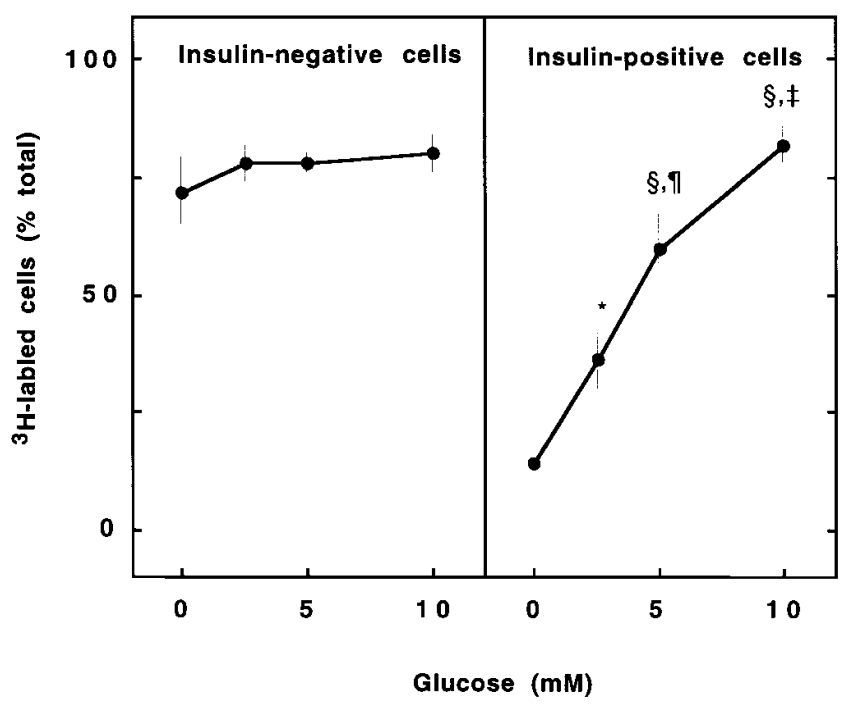

Figure 3. Effect of glucose on the percent insulin-negative (left) and insulin-positive (right) cells with $\left[{ }^{3} \mathrm{H}\right]$ tyrosine incorporation. Glucose dose-dependently recruits insulin-positive cells into biosynthetic activity. Insulin-negative cells are activated irrespective of the glucose concentration. Data represent means \pm SEM from four to nine independent experiments. Statistical significance of differences with 0 $\mathrm{mmol} /$ liter glucose $(* \S)$ and with the preceding glucose level $(\ddagger$ II) is calculated by ANOVA. ${ }^{\ddagger} P<0.05 ; * \|\left[P<0.01 ;{ }^{\S} P<0.001\right.$.

synthesis. In the absence of glucose, $7 \%$ of newly formed protein corresponded to insulin immunoreactive material; glucose dose-dependently increased this ratio up to $25 \%$ at $10 \mathrm{mmol} / \mathrm{li}$ ter. Synthesis of noninsulin proteins was not significantly increased by glucose (Fig. 1).

The ${ }^{3} \mathrm{H}$-labeled preparations were also examined in autoradiographs to determine the percentage of cells that were biosynthetically active. More than $70 \%$ of insulin-negative cells were already intensely labeled in the absence of glucose (Figs. 2 and 3); addition of glucose did not further increase the percentage of insulin-negative cells in active biosynthesis (Fig. 3). In contrast, only a few insulin-positive $\beta$ cells were labeled in the absence of glucose, while glucose recruited, dose-depen-
Table II. Effect of Glucose Concentration during Culture on Glucose-inducible Insulin Synthesis

\begin{tabular}{cccc}
\hline & \multicolumn{2}{c}{ (Pro)insulin synthesis } & \\
\cline { 2 - 3 } $\begin{array}{c}\text { Culture } \\
\text { condition }\end{array}$ & $\begin{array}{c}\text { Glucose } \\
0 \text { mmol/liter }\end{array}$ & $\begin{array}{c}\text { Glucose } \\
10 \mathrm{mmol} / \text { liter }\end{array}$ & Net increase* \\
\hline & & $f m o l / 10^{3} \beta$ cells/2 $h$ & \\
1 or 2 d at glucose & & & \\
$6 \mathrm{mmol} /$ liter & $7 \pm 2$ & $40 \pm 4$ & $(35 \pm 6)$ \\
$7 \mathrm{~d}$ at glucose & & & \\
$3 \mathrm{mmol} /$ liter & $5 \pm 2$ & $17 \pm 4$ & $(12 \pm 3)$ \\
$6 \mathrm{mmol} /$ liter & $7 \pm 2$ & $31 \pm 6$ & $(24 \pm 6)$ \\
$10 \mathrm{mmol} /$ liter & $22 \pm 3^{\ddagger}$ & $37 \pm 8$ & $(15 \pm 6)$ \\
$20 \mathrm{mmol} /$ liter & $24 \pm 8^{\ddagger}$ & $28 \pm 5$ & $(4 \pm 3)^{\S}$ \\
& & & \\
\hline
\end{tabular}

*Net increase is calculated as the difference between 10 and $0 \mathrm{mmol} / \mathrm{li}-$ ter glucose. Data represent means \pm SEM of five to seven independent experiments. Statistical significance of differences with $6 \mathrm{mmol} / \mathrm{liter}$ glucose culture condition was calculated by ANOVA. ${ }^{\ddagger} P<0.05,{ }^{\S} P<0.01$.

dently, more $\beta$ cells into biosynthetic activity (Figs. 2 and 3). This glucose-induced recruitment is most pronounced between 0 and $5 \mathrm{mmol} /$ liter, leading to an additional $46 \pm 6 \%$ of $\beta$ cells into protein synthesis (Fig. 3). Raising the glucose concentration from 5 to $10 \mathrm{mmol} /$ liter recruited another $20 \pm 5 \%$ of $\beta$ cells (Fig. 3). At $10 \mathrm{mmol} /$ liter glucose, $10-20 \% \beta$ cells remained biosynthetically inactive (Fig. 3).

Effect of prolonged exposure to low or high glucose levels on subsequent glucose responsiveness of $\beta$ cells. After $7 \mathrm{~d}$ of culture, the insulin biosynthetic activity of human islets was measured over $2 \mathrm{~h}$ of incubation at different concentrations of glucose. The data were expressed as function of the number of islet or $\beta$ cells present in the islet preparations (see Methods). In the control preparations, cultured at $6 \mathrm{mmol} / \mathrm{liter}$ glucose, raising the glucose concentration from 0 to $20 \mathrm{mmol} / \mathrm{liter}$ dosedependently increased the rates of insulin synthesis, up to fourfold higher rates with a half-maximal effect at $5 \mathrm{mmol} / \mathrm{liter}$ and maximal effect at $10 \mathrm{mmol} /$ liter (Fig. 4). Basal and maximal synthetic activities were comparable with the values measured in

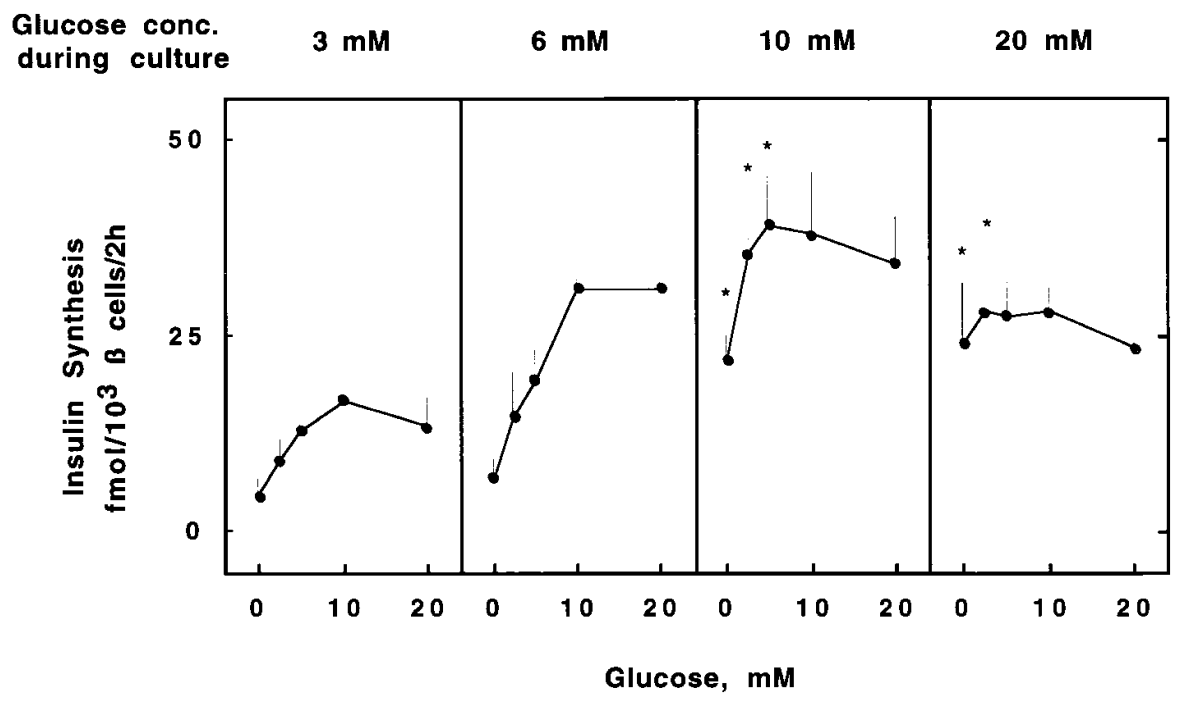

Figure 4. Effect of glucose on insulin synthesis by human islets after $7 \mathrm{~d}$ of culture at $3,6,10$, or $20 \mathrm{mmol} /$ liter glucose. Data are expressed per $10^{3} \beta$ cells and represent means \pm SEM from five to seven independent experiments. Statistical significance of differences with $6 \mathrm{mmol} /$ liter glucose cultured cells is calculated by ANOVA. $* P<0.05$. 

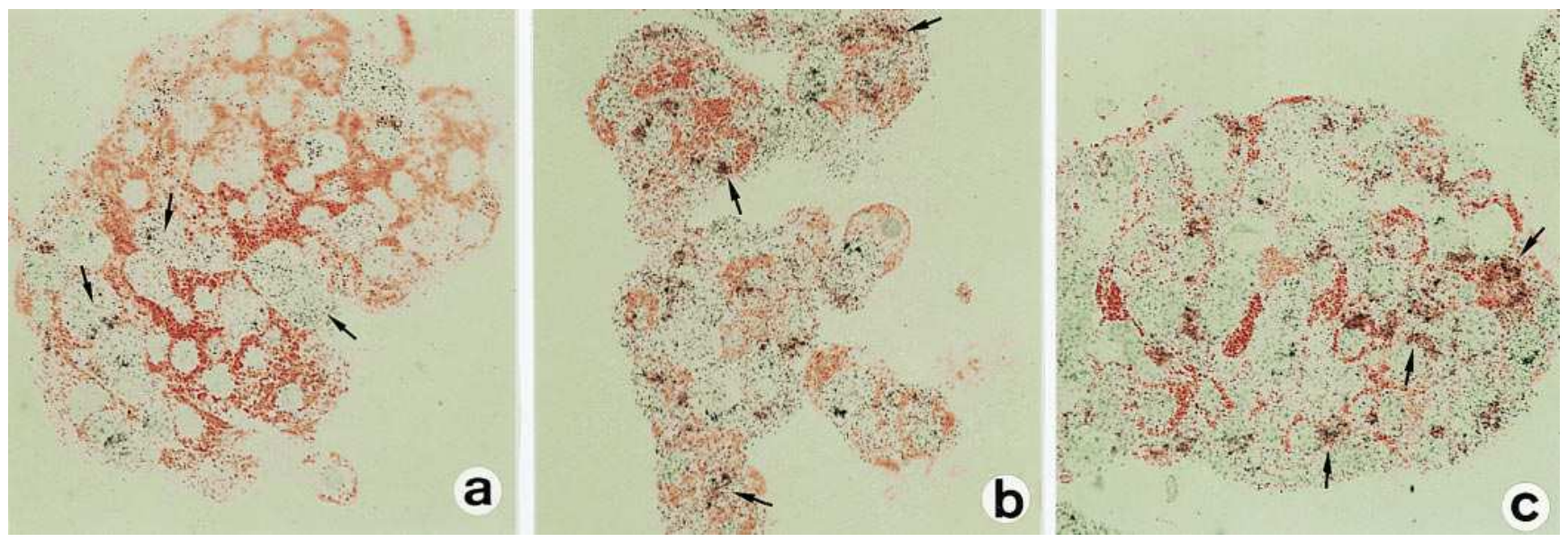

Figure 5. Effect of glucose upon $\left[{ }^{3} \mathrm{H}\right]$ tyrosine incorporation by human islet cells after $7 \mathrm{~d}$ of culture at $6 \mathrm{mmol} / \mathrm{liter}(a$ and $b)$ or $20 \mathrm{mmol} / \mathrm{liter}$ glucose $(c)$. Autoradiographs of 1- $\mu \mathrm{m}$ islet sections are shown after immunostaining for insulin and counterstaining with hematoxylin. The preparations were incubated with $\left[{ }^{3} \mathrm{H}\right]$ tyrosine for $2 \mathrm{~h}$ in the absence of glucose $(a$ and $c)$ or with $10 \mathrm{mmol} /$ liter glucose $(b)$. After culture at $6 \mathrm{mmol} / \mathrm{liter}$ glucose, the majority of silver grains accumulated in insulin-negative cells in the absence of glucose ( $a$, arrow); most of the insulin-positive cells (stained in red) became positive at $10 \mathrm{mmol} /$ liter glucose (b, arrow). After culture at $20 \mathrm{mmol} /$ liter glucose, virtually all cells were activated in the absence of glucose $(c)$. The hematoxylin staining is very weak in these preparations; nuclei are faintly blue. $\times 1020$.

1- or 2-d cultured preparations (Table II). Culture at $3 \mathrm{mmol} /$ liter glucose markedly reduced the maximal levels of glucoseinducible insulin synthesis, whereas culture at $10 \mathrm{mmol} / \mathrm{liter}$ glucose increased the basal rates and shifted the dose-response curve to the left with a half-maximal effect at $1 \mathrm{mmol} /$ liter and maximal effect at $2.5 \mathrm{mmol} /$ liter glucose (Fig. 4). After culture at $20 \mathrm{mmol} /$ liter glucose, the cells exhibited the same high basal activity as after $10 \mathrm{mmol} /$ liter glucose, but they were no longer responsive to the glucose stimulation (Fig. 4 and Table II). Consequently, the net glucose effect upon insulin synthesis, calculated as the difference between the rates at 10 and 0 $\mathrm{mmol} /$ litr, was markedly reduced after culture at $10 \mathrm{mmol} /$ liter and disappeared completely after culture at $20 \mathrm{mmol} / \mathrm{liter}$ (Table II).

The observed differences in basal activity were the result of differences in the number of $\beta$ cells that were biosynthetically active at $0 \mathrm{mmol} /$ liter glucose. The protein synthetic activity of individual cells was analyzed in autoradiographs of sections of islets labeled during incubation in glucose-free medium. After culture at $6 \mathrm{mmol} /$ liter glucose, only a few insulin-positive cells incorporated the radioactive amino acid; most grains accumulated in insulin-negative cells (Fig. 5 a). After culture at 20 $\mathrm{mmol} /$ liter glucose, most cells were intensely labeled, thus indicating that most insulin-positive cells were biosynthetically active in glucose-free medium (Fig. $5 c$ ).

Effect of prolonged exposure to high glucose levels on subsequent secretory activity of cultured human $\beta$ cells. The effect of culture at $20 \mathrm{mmol} /$ liter glucose was also examined on the secretory responsiveness of the cells. The islet preparations were carried on perifusion columns and submitted to glucose pulses at increasing concentrations. Control islets were cultured at $6 \mathrm{mmol} /$ liter glucose. At $2.5 \mathrm{mmol} /$ liter glucose, the $20 \mathrm{mmol} /$ liter cultured islets released twofold more insulin than the controls (Fig. 6 and Table III); however, they did not respond to a $5 \mathrm{mmol} /$ liter glucose pulse while control islets were stimulated threefold. A secretory response was elicited by a $10 \mathrm{mmol} /$ liter glucose pulse, but the amount of released hormone was markedly lower than in control preparations. At
$20 \mathrm{mmol} /$ /iter glucose, both preparations exhibited a biphasic release (Fig. 6 and Table III). Since the lower insulin content of the $20 \mathrm{mmol} /$ liter cultured cells (Table I) may contribute to their lower secretory output, insulin release was also expressed as a percentage of the cellular hormone content that was measured at the start of the perifusion (Fig. 6 and Table III). In this mode of expression, basal discharge from $20 \mathrm{mmol} /$ liter cultured cells was ninefold higher than that from $6 \mathrm{mmol} /$ liter cultured cells; their first phase release during the 10 and $20 \mathrm{mmol} /$ liter glucose pulses represented similar fractions of stored insulin than that from $6 \mathrm{mmol} /$ liter cultured cells and their second phase release was even higher. Over the entire 90-min perifusion test, the $20 \mathrm{mmol} /$ liter cultured cells released $18 \%$ of their hormone content, while the control cells secreted only $7 \%$ (Table III).

\section{Discussion}

This study demonstrated that human islet preparations can be cultured for at least $1 \mathrm{wk}$ without considerable losses in the number and functions of the $\beta$ cells. Culture is carried out in the same serum-free medium as previously selected for rat $\beta$ cells (29) except for lower glucose concentrations $(6 \mathrm{mmol} /$ liter instead of $10 \mathrm{mmol} /$ liter for rat cells) and the absence of IBMX. After 1 wk of culture, $80 \%$ of the initial $\beta$ cell number is recovered with a comparable insulin content as at start. The presence of lower ( $3 \mathrm{mmol} / \mathrm{liter})$ or higher $(10$ and $20 \mathrm{mmol} /$ liter) glucose levels leads to lower cellular insulin reserves. This reduction is attributable to a decreased rate of insulin production at low glucose levels, whereas it results from an imbalance between the increased rates of insulin production and release at high glucose levels.

After 1 or $2 \mathrm{~d}$ of culture at $6 \mathrm{mmol} /$ liter glucose, the human $\beta$ cells exhibited a potent functional responsiveness to glucose, as illustrated by the five- to sixfold increase in proinsulin synthesis. The glucose-induced increase in hormone production was mediated by a dose-dependent activation of $\beta$ cells, as has been observed previously in rat $\beta$ cells (21-24). A rise in glu- 


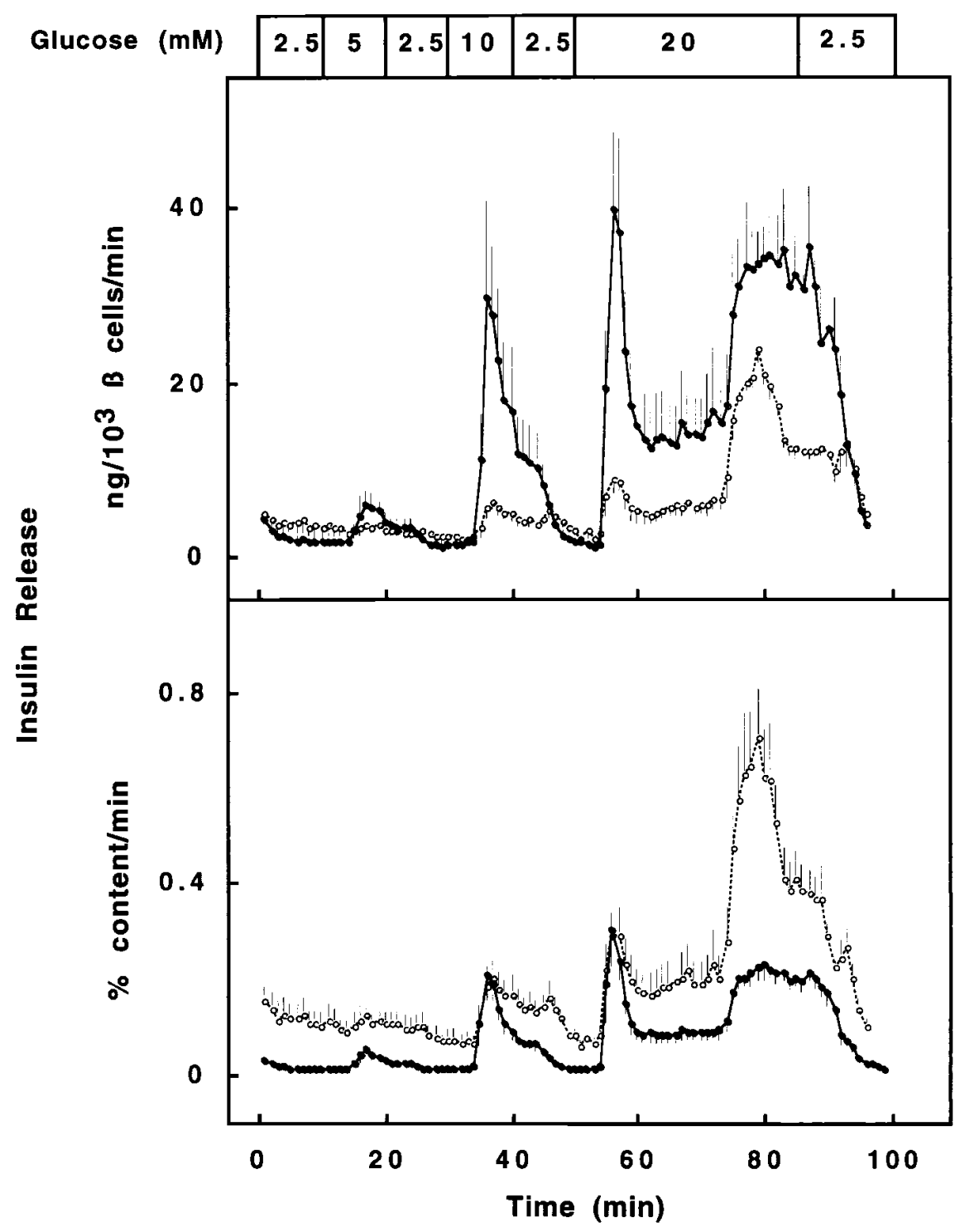

Figure 6. Insulin release from human islets after $7 \mathrm{~d}$ of culture at $6 \mathrm{mmol} /$ liter (filled circles) or $20 \mathrm{mmol} /$ liter (open circles) glucose. The preparations were perifused with 10 min pulses of varying glucose concentration. The rate of insulin release per minute is expressed per $10^{3} \beta$ cells (top) or as a function of the cellular insulin content (bottom). Data represent means \pm SEM from six independent experiments. cose from 0 to $5 \mathrm{mmol} / \mathrm{liter}$ recruited $45 \% \beta$ cells into biosynthetic activity and elevated insulin synthesis from 20 to $65 \%$ of its maximal rates. At $10 \mathrm{mmol} / \mathrm{liter}$ glucose, $80-85 \%$ of the $\beta$ cells were activated. It is not yet known whether the $15-20 \%$ glucose-unresponsive cells require other stimuli for activation or whether they represent an inactive or impaired state of the cells. The glucose-dependent recruitment of cells was specific for the insulin-containing cells: in the insulin-negative cell population, $75 \%$ of the cells were active irrespective of the glucose concentration. These results indicate that the human pancreatic $\beta$ cell population is composed of cells which differ in their individual sensitivity to glucose, a property that determines the shape of their dose-response curves to acute glucose stimulation. This cellular heterogeneity has also been noticed when human $\beta$ cells were compared for their threshold of glucoseinducible calcium oscillations (30). The concept of functional heterogeneity in the $\beta$ cell population $(21,22)$ can thus be extended from the rat to the human species.

After $7 \mathrm{~d}$ of culture at $6 \mathrm{mmol} /$ liter glucose, the glucose responsiveness of human $\beta$ cells was well preserved, as judged by the 4 - to 5-fold increase in proinsulin synthesis and 20-fold in- crease in insulin release. Culture at lower $(3 \mathrm{mmol} / \mathrm{liter})$ or at higher (10 or $20 \mathrm{mmol} /$ liter) glucose did not result in a lower recovery of $\beta$ cells, at least not after $1 \mathrm{wk}$, but markedly impaired their functional state. After culture at $3 \mathrm{mmol} / \mathrm{liter}$ glucose, the human $\beta$ cell population exhibited a marked reduction in its insulin biosynthetic capacity during an acute stimulation by glucose. A similar finding has been made previously for rat $\beta$ cells after culture at 6 instead of $10 \mathrm{mmol} / \mathrm{liter}$ glucose, a phenomenon attributed to an increase in the proportion of glucose-unresponsive cells (19). After culture at 10 and $20 \mathrm{mmol} /$ liter glucose, the human $\beta$ cells were capable of achieving the same maximal rates of insulin biosynthesis as after $6 \mathrm{mmol} /$ liter culture, but these rates were already achieved when the cells were examined at $2.5 \mathrm{mmol} /$ liter glucose or lower. By looking only at the shape of the dose-response curves after culture at elevated glucose levels, i.e., the small gain in amplitude for a rise in glucose concentration, one could infer that the $\beta$ cells exhibit a state of inactivity or glucose insensitivity. However, our study indicates that such interpretation is incorrect. Indeed, this culture condition was found to induce a prolonged state of activation in the majority of $\beta$ cells, 
Table III. Effect of Glucose Concentration during Culture on Glucose-inducible Insulin Release

\begin{tabular}{|c|c|c|c|}
\hline \multirow[b]{2}{*}{ Culture condition } & \multicolumn{3}{|c|}{ Insulin release* } \\
\hline & Basal & Stimulated & Total \\
\hline & \multicolumn{2}{|c|}{$\mathrm{fmol} / 10^{3} \beta \mathrm{cell} / \mathrm{min}$} & $\mathrm{fmol} / 10^{3} \beta$ cells $/ 90 \mathrm{~min}$ \\
\hline Glucose $6 \mathrm{mmol} /$ liter & $0.3 \pm 0.1$ & $5.6 \pm 1.5$ & $186 \pm 44$ \\
\hline \multirow[t]{2}{*}{ Glucose $20 \mathrm{mmol} /$ liter } & $0.6 \pm 0.2$ & $1.3 \pm 0.3$ & $92 \pm 14^{\ddagger}$ \\
\hline & \multicolumn{2}{|c|}{$\%$ cellular content/min } & $\begin{array}{l}\% \text { cellular content/ } \\
90 \mathrm{~min}\end{array}$ \\
\hline Glucose $6 \mathrm{mmol} /$ liter & $0.01 \pm 0.003$ & $0.25 \pm 0.06$ & $7 \pm 1$ \\
\hline Glucose $20 \mathrm{mmol} /$ liter & $0.11 \pm 0.03^{\ddagger}$ & $0.28 \pm 0.05$ & $18 \pm 3^{\ddagger}$ \\
\hline
\end{tabular}

* Insulin release was measured during 90 min of perifusion. Basal (at 2.5 $\mathrm{mmol} /$ liter glucose) and stimulated (at $20 \mathrm{mmol} /$ liter glucose) release are expressed per minute. Total represents the amount released over the 90-min perifusion. Data are taken from the experiments shown in Fig. 6 and represent means \pm SEM of six experiments. Statistical significance of differences with $6 \mathrm{mmol} /$ liter glucose culture condition was calculated by Student's $t$ test. $P<0.01$.

which was maintained when the cells were subsequently kept at low or even in the absence of glucose, indicating a hyperactivity of the cells. This state is maintained for a minimum of $24 \mathrm{~h}$ in the presence of basal glucose levels (our unpublished observations). Prolonged exposure to high glucose resulted in a loss of the intercellular heterogeneity and thus eliminated the dose-dependent cellular activation as a mechanism to adjust functional responses to acute variations in glucose concentrations within the physiologic range. This conclusion is at variance with that of Eizirik et al. (14) who reported that the metabolic and insulin biosynthetic activities of human islets are reduced after $7 \mathrm{~d}$ of culture at $28 \mathrm{mmol} /$ liter instead of 5.6 $\mathrm{mmol} / \mathrm{liter}$ glucose. This discrepancy may result from the use (in reference 14) of a different culture condition, i.e., RPMI medium with $10 \%$ fetal calf serum. It may also be attributable to another method of data expression: we have chosen to express our data as a function of the number of $\beta$ cells and not as a function of islet number, which can, in itself, be subject to variations.

The poor rise in the insulin release rates after glucose stimulation is thus not necessarily a sign for a failure of glucose to activate the pancreatic $\beta$ cell population. After culture at 20 $\mathrm{mmol} / \mathrm{liter}$ glucose, release rates were only twofold higher after maximal glucose stimulation than at basal levels $(2.5 \mathrm{mmol} /$ liter glucose). When hormone release was expressed as a function of the cellular hormone content, this impaired amplification by glucose was not associated with a reduced secretory activity but, on the contrary, associated with a 10-fold higher basal activity than that in control cells. This is in line with our observations on the biosynthetic activity of the cells. Our data are also comparable with those obtained previously in both in vivo and in vitro models of hyperglycemia $(16,17,31-34)$. This study emphasizes that the insulin levels measured at low or at high glucose cannot be taken as an adequate parameter for the secretory activity of the $\beta$ cells, if they cannot be expressed as a function of the number of $\beta$ cells and their hormone content. Prolonged exposure to high glucose resulted in markedly lower hormone stores and, hence, reduced the amounts that were released by activated cells. However, restoration of insulin stores in human $\beta$ cells is not always sufficient to normalize their glucose-inducible insulin secretion (11). In patients with non-insulin-dependent diabetes, the chronically elevated glucose levels can be expected to influence the secretory responsiveness of the $\beta$ cells via two mechanisms, first through the reduction in the cellular insulin stores, and secondly by increasing the proportion of $\beta$ cells that remain activated irrespective of acute variations in glucose. Both mechanisms will, in themselves, result in an impaired rise in circulating insulin levels after glucose stimulation. Therefore, the latter observation is not necessarily a sign for an inactive or glucose-desensitized $\beta$ cell population. It may, instead, express a hyperactivated state of the cells with a loss in functional heterogeneity. While the present in vitro study over $7 \mathrm{~d}$ indicates that both mechanisms can develop in normal human $\beta$ cells, it does not provide evidence for their existence in non-insulin dependent diabetes mellitus patients whose $\beta$ cells may exhibit a constitutive abnormality and where, furthermore, longer periods of hyperglycemia occur.

\section{Acknowledgments}

The authors thank the personnel of the central unit of $\beta$-Cell Transplant for preparing the human islets cells; René De Proft, Lutgart Heylen, Geert Stangé, and Gabriel Schoonjans for technical assistance in the present work, Run-Nian Wang for morphologic illustration, and Decio Eizirik for proofreading the manuscript.

This work was supported by grants from the European Community (BMH1-CT92-0805, BMH4-CT95-1561), from the Ministry of Scientific Policy (CE-03-001), from the Flemish Community (93/019, Biomed), and from the Juvenile Diabetes Foundation International (DIRP 995004)

\section{References}

1. Weir, G.C., and J.L. Leahy. 1994. Pathogenesis of non-insulin-dependent (type II) diabetes mellitus. In Joslin's Diabetes Mellitus, 13th. C.R. Hahn and G.C. Weir, editors. Lea \& Febiger, Malvern, PA. 240-264.

2. Yki-Järvinen, H. 1992. Glucose toxicity. Endocr. Rev. 13:415-431

3. DeFronzo, R.A., R.C. Bonadonna, and E. Ferrannini. 1992. Pathogenesis of NIDDM. A balanced overview. Diabetes Care. 15:318-368.

4. Leahy, J.L. 1990. Natural history of $\beta$-cell dysfunction in NIDDM. Diabetes Care. 13:992-1010.

5. Robertson, R.P., L.K. Olson, and H.J. Zhang. 1994. Differentiating glucose toxicity from glucose desensitization: a new message from the insulin gene. Diabetes. 43:1085-1089.

6. Robertson, R.P. 1989. Type II diabetes, glucose "non-sense," and islet desensitization. Diabetes. 38:1501-1505.

7. Leahy, J.L., S. Bonner-Weir, and G.C. Weir. 1984. Abnormal glucose regulation of insulin secretion in models of reduced B-cell mass. Diabetes. 33: $667-673$.

8. Leahy, J.L., H.E. Cooper, D.A. Deal, and G.C. Weir. 1986. Chronic hyperglycemia is associated with impaired glucose influence on insulin secretion: a study in normal rats using chronic in vivo glucose infusions. J. Clin. Invest. 77: 908-915.

9. Bonner-Weir, S., D.F. Trent, and G.C. Weir. 1983. Partial pancreatectomy in the rat and subsequent defect in glucose-induced insulin release. $J$. Clin. Invest. 71:1544-1553.

10. Korsgren, O., J. Jansson, S. Sandler, and A. Andersson. 1990. Hyperglycemia-induced B-cell toxicity. The fate of pancreatic islets transplanted into diabetic mice is dependent on their genetic background. J. Clin. Invest. 86:21612168.

11. Jansson, L., D.L. Eizirik, D.G. Pipeleers, L.A.H. Borg, C. Hellerström, and A. Andersson. 1995. Impairment of glucose-induced insulin secretion in human pancreatic islets transplanted to diabetic nude mice. J. Clin. Invest. 93: 721-726.

12. Bolaffi, J.L., L. Bruno, A. Heldt, and G.M. Grodsky. 1988 Characteristics of desensitization of insulin secretion in fully in vitro system. Endocrinology. 122:1801-1809.

13. Davalli, A.M., A.E. Pontiroli, C. Socci, F. Bertuzzi, B. Fattor, S. Braghi, 
V. Di Carlo, and G. Pozza. 1992. Human islets chronically exposed in vitro to different stimuli become unresponsive to the same stimuli given acutely: evidence supporting specific desensitization rather than $\beta$-cell exhaustion. J. Clin. Endocrinol. \& Metab. 74:790-794.

14. Eizirik, D.L., G.S. Korbutt, and C. Hellerström. 1992. Prolonged exposure of human pancreatic islets to high glucose concentrations in vitro impairs the $\beta$-cell function. J. Clin. Invest. 90:1263-1268.

15. Purrello, F., M. Vetri, C. Gatta, D. Gullo, and R. Vigneri. 1989. Effects of high glucose on insulin secretion by isolated rat islets and purified $\beta$-cells and possible role of glycosylation. Diabetes. 38:1417-1422.

16. Leahy, J.L., M. Bumbalo, and C. Chen. 1993. Beta cell hypersensitivity for glucose precedes loss of glucose-induced insulin secretion in $90 \%$ pancreatectomized rats. Diabetologia. 36:1238-1244.

17. Thibault, C., C. Guettet, M.C. Laury, J.M. N'Guyen, T.A. Tormo, B. Portha, L. Pénicaud, and A. Ktorza. 1993. In vivo and vitro increased pancreatic beta-cell sensitivity to glucose in normal rats submitted to a 48-h hyperglycaemic period. Diabetologia. 36:589-595.

18. Hoenig, M., L.C. MacGregor, and F.M. Matschinsky. 1986. In vitro exhaustion of pancreatic $\beta$-cells. Am. J. Physiol. 250 (Endocrinol. Metab. 13): E502-E511.

19. Ling, Z., R. Kiekens, T. Mahler, F.C. Schuit, M. Pipeleers-Marichal, S. Abdullah, K. Gunther, W.L. Malaisse, and D.G. Pipeleers. 1996. Effects of chronically elevated glucose levels on the functional properties of rat pancreatic beta cells. Diabetes. In press.

20. De Vos, A., H. Heimberg, E. Quartier, P. Huypens, L. Bouwens, D. Pipeleers, and F. Schuit. 1996. Human and rat beta cells differ in glucose transporter but not in glucokinase gene expression. J. Clin. Invest. 96:2489-2495.

21. Pipeleers, D. 1992. Heterogeneity in pancreatic $\beta$-cell population. Diabetes. 41:777-781.

22. Pipeleers, D., R. Kiekens, Z. Ling, A. Wilikens, and F. Schuit. 1994. Physiologic relevance of heterogeneity in pancreatic $\beta$ cell population. Diabetologia. 37(Suppl. 2):S57-S64.

23. Schuit, F.C., P.A. In't Veld, and D.G. Pipeleers. 1996. Glucose stimulated proinsulin biosynthesis by a dose-dependent recruitment of pancreatic beta cells. Proc. Natl. Acad. Sci. USA. 85:3865-3869.

24. Kiekens, R., P.A. In’t Veld, T. Mahler, F.C. Schuit, M. Van De Winkel, and D.G. Pipeleers. 1991. Differences in glucose recognition by individual rat pancreatic B cells are associated with intercellular differences in glucose-induced biosynthetic activity. J. Clin. Invest. 89:117-125.

25. Warnock, G.L., D.K. Ellis, M. Cattral, D. Untch, N.M. Kneteman, and R.V. Rajotte. 1989. Viable purified islets of Langerhans from collagenase-perfused human pancreas. Diabetes. 38(Suppl. 1):136-139.

26. Pipeleers, D.G., P.A. In't Veld, M. Van De Winkel, E. Maes, F.C. Schuit, and W. Gepts. 1985. A new in vitro model for the study of pancreatic A and B cells. Endocrinology. 117:806-816.

27. Pipeleers, D.G., and M. Van De Winkel. 1986. Pancreatic B cells possess defense mechanism against cell-specific toxicity. Proc. Natl. Acad. Sci. USA. 83 5267-5271.

28. Van Schravendijk, C., R. Kiekens, and D.G. Pipeleers. 1992. Pancreatic $\beta$ cell heterogeneity in glucose-induced insulin secretion. J. Biol. Chem. 25 21344-21348.

29. Ling, Z., and D.G. Pipeleers. 1994. Preservation of glucose-responsive islet beta cells during serum-free culture. Endocrinology. 134:2614-2621.

30. Hellman, B., E. Gylfe, P. Bergsten, E. Grapengiesser, P.E. Lund, A Tengholm, D.G. Pipeleers, and Z. Ling. 1994. Glucose induces oscillatory $\mathrm{Ca}^{2+}$ signalling and insulin release in human pancreatic beta cells. Diabetologia. 37(Suppl. 2):S11-S20.

31. Hansen, B.C., and N.L. Bodkin. 1990. $\beta$-cell hyperresponsiveness: earliest event in the development of diabetes in monkeys. Am. J. Physiol. 259:R612R617.

32. Andersson, A., J. Westman, and C. Hellerström. 1974. Effects of glucose on the ultrastructure and insulin biosynthesis of isolated mouse pancreatic islets maintained in tissue culture. Diabetologia. 10:743-753.

33. Liang, Y., H. Najafi, R.M. Smith, E.C. Zimmol/Lerman, M.A. Magnuson, M. Tal, and F.M. Matschinsky. 1992. Concordant glucose induction of glucokinase, glucose usage, and glucose-stimulated insulin release in pancreatic islets maintained in organ culture. Diabetes. 41:792-806.

34. Purrello, F., M. Buscema, A.M. Rabuazzo, V. Caltabiano, F. Forte, C. Vinci, M. Vetri, and R. Vigneri. 1993. Glucose modulates glucose transporter affinity, glucokinase activity, and secretory response in rat pancreatic $\beta$-cells. Diabetes. 42:199-205. 